\title{
Diversity and Abundance of Pollinators Fauna in Phalsa Grewia subinaequalis D.C
}

\author{
Avinash Udikeri* and Umesh Chandra
}

Department of Entomology, College of Agriculture, Faizabad, Narendra Deva of University of Agriculture and Technology, Kumarganj, Faizabad-224 229, Uttar Pradesh, India

*Corresponding author

\begin{tabular}{|c|c|}
\hline \multicolumn{2}{|r|}{ A B S T R A C T } \\
\hline & \multirow{6}{*}{$\begin{array}{l}\text { A study was carried out to know the diversity and abundance pollinator fauna on Phalsa, } \\
\text { Grewia subinaequalis D.C. a fruiting shrub at Main Experimental Station Horticulture } \\
\text { Narendra Deva University of Agriculture and Technology, Kumarganj, Faizabad (U.P) } \\
\text { during year } 2015 \text {. A total of nineteen different insect species were found visiting the } \\
\text { Phalsa flowers. Thirteen insect species belonging to the families Megachilidae ( } 3 \text { spp) } \\
\text { Vespidae }(2 s p p) \text {, Apidae }(5 s p p) \text {, Halictidae ( } 1 s p \text {. }) \text {, Xylocopidae }(2 s p p \text {.) of the order } \\
\text { Hymenoptera have been recognised as active pollinators of Phalsa. Three Dipterans } \\
\text { belonging to the family sarcophagidae, Calliphoridae and Syrphidae found to pollinate thi } \\
\text { fruit crop. Three butterflies which are of Pieridae, Nymphalidae and Amatidae families are } \\
\text { found to visit the flowers of the Phalsa. Apis dorsata, A. mellifera, Megachile spp, Halictus } \\
\text { Sp. were abundant pollinators. The foraging activity started from April month. The } \\
\text { abundance of Halictus sp. was highest with } 4.38 \text { bees/branch/5min followed by Megachile } \\
\text { sp. (3.88bees/branch/5min) and A.dorsata ( } 2.89 \text { bees/branch } / 5 \mathrm{~min}) \text {. Dipterans and } \\
\text { Lepidopterans were less abundant. }\end{array}$} \\
\hline Keywords & \\
\hline $\begin{array}{l}\text { Pollinators, } \\
\text { Relative } \\
\text { abundance, Phalsa }\end{array}$ & \\
\hline Article Info & \\
\hline $\begin{array}{l}\text { Accepted: } \\
\text { 18 January } 2019 \\
\text { Available Online: } \\
\text { 10 February } 2019\end{array}$ & \\
\hline & \\
\hline
\end{tabular}

\section{Introduction}

Grewia subinaequalis D.C. (Malvaceae), commonly known as 'Phalsa' is a multipurpose gregarious shrub, found in tropical and subtropical parts of India. It is an invasive species indigenous in the Indian subcontinent and South-Eastern Asia. The genus comprises approximately 150 species of small trees and shrubs, distributed in subtropical and tropical regions of the world and it is the only genus in its family that yields edible fruits (Ullah et al., 2012). Phalsa is a cross-pollinated fruit crop and pollination is done by the insects such as honey bees, wasp, hover flies etc. Phalsa flower comes in last week of February and the fruits ripe in the second forth night of April and continuous upto middle of June.

It is minor fruit and is being cultivated on very small scale in each state. Phalsa is found wildly growing in UP, Rajasthan, Punjab, Haryana, MP, West Bengal and many parts of south India. The cultivation of Phalsa is limited to very small scale. Most of the commercial plantations are adjoining to big cities. However, in Punjab, Haryana and Uttar 
Pradesh it is cultivated near cities commercially. In Punjab area under Phalsa is only 30 hectares with annual production of 196 tonnes approximately. The total area under Phalsa is less than 1000 ha. The popularity of this crop is restricted due to small fruit size, prolonged ripening period, repeated harvesting and highly perishable nature of fruits.

The current statistics on area and production of this fruit are not available. Apart from India it is cultivated in Pakistan, Nepal, Bangladesh, Laos, Sri Lanka, Thailand, Philippines, Vietnam and experimental basis in some provinces of United States of America.

The fruits are claimed to be useful for heart, blood and liver disorders. Anorexia, indigestion, thirst, toxaemia, stomatitis, hiccough, asthma, spermatorrhoea, fever, diarrhoea, tuberculosis and sexual troubles are some other ailments where Phalsa fruits are effective (Mishra et al., 2012; Pallavi et al., 2011; Sharma and Sisodia, 2009). Keeping in view of these important medicinal properties present investigation was done to know about which are the important insect species which help to set the fruits of Phalsa.

\section{Materials and Methods}

The investigations were carried in an well established phalsa plantation (cv.Dwarf variety) at Main Experimental Station, Department of Horticulture, Narendra Deva University of Agriculture and Technology, Kumarganj, Faizabad (U.P.) Geographically, it is situated at $26.47^{\circ} \mathrm{N}$ latitude, $82.12^{0} \mathrm{E}$ longitude and altitude of 113 metres above mean sea level. The site is located in typical saline-alkaline belt of indogangetic plains of eastern Uttar Pradesh. The experiment site was having sodic soils. The shrubs of phalsa were two years old.
Faunistic spectrum of insects visiting the flowers of Phalsa

The insects visiting phalsa flowers were keenly observed throughout the blooming period at weekly intervals during April to May months at hourly intervals in morning and noon. These insects were collected by using a cone type hand net having $30 \mathrm{~cm}$ ring diameter. Swift sweeping method was adopted to collect the insects and they specimen were processed for identification. Identification was done using taxonomic keys by Dr. Umesh Chandra, Project coordinator, AICRP on honey bees, NDUAT, Faizabad.

\section{Abundance of insect visitors/pollinators on Phalsa flowers}

Abundance of different insect visitors/pollinators on Phalsa flowers mentioned above was studied during their blooming period. The total number of different insects visiting on the number of Phalsa flowers was observed on randomly selected five plants between 0800-1000, 1000-1200 and 1400-1600 h of the day. These observations were started at 50 per cent flowering and continued upto $90 \%$ flowering.

The data on relative abundance was subjected for statistical analyses suitably

All the data pertaining to relative abundance was statistically analyzed by using Randomised block design. The effect of bee pollination on different aspects of yield, the statistical analyses of data were performed for analysis of variance as outlined by Gomez et al., (1984).

From the above analysis, standard error of mean $(\mathrm{SEm} \pm)$ as well as, critical difference was calculated at 5\% level of probability calculated to test the significance of mean for the treatment differences. 


\section{Results and Discussion}

\section{Documentation of pollinators on Phalsa}

Phalsa is cross pollinated fruit crop which attracts more number of pollinators during its booming period. Insect visitors and pollinators collected from Phalsa crop have been listed in Table 1. A total of nineteen different insect species belonging to eleven families from three orders were documented from the Phalsa flowers.

The Hymenopterans were the major floral pollinators comprising of thirteen species from four families viz. Apidae, Vespidae, Megachilidae, Halictidae and Xylocopidae. Three species of the families Sarcophagidae, Calliphoridae, Syrphidae belonging to order Diptera and three species of families Nymphalidae, Pieridae, Amatidae belonging to Lepidoptera were found to be pollinating the flowers of Phalsa..

\section{Relative abundance of different insect pollinators}

The data on the frequency of different insect visitors (Total number of bees/branch/5 min.) irrespective of different plant types have been presented in Table 2. It revealed that the pooled averages of all the insect visitors, irrespective of species, on three observational hours (0800 to 1000,1000 to 1200 and 1400 to $1600 \mathrm{~h}$ of the day) during first (8th April to 17th April), second (19th April to 28th April) and third (30th April to 9th May) interval observations were $2.93,2.52,2.24,3.77,3.32$, $2.88,2.03,1.59$ and 1.31 number of bees/branch/5 min., respectively. During first interval, the frequency of insect visitors differed significantly.

Halictus sp. was significantly superior over all the insect species at different hours of the day. At $1400-1600 \mathrm{~h}$ of the day activity of
Apis dorsata was on par with Apis mellifera. During second interval, Halictus sp. was significantly superior over all the insect species at different hours of the day. At 1400$1600 \mathrm{~h}$ of the day, activity of Apis mellifera was on par with the Polistes olivaceus. During third interval, the activity of Halictus $s p$. remained significantly superior compared to other insects' species at different hours of the day. The activity of Apis dorsata was on par with Apis mellifera at 1000-1200 and 1400-1600 $\mathrm{h}$ of the day. The activity of Halictus $s p$. was significantly higher at all the three hours of the day during all the three intervals which was followed by Megachile sp., Apis dorsata, Apis mellifera, Polistes olivaceus, Dipterans and Lepidopterans.

Irrespective of three observational hours, Halictus sp. with 4.66, 5.60 and 2.86 bees/branch/5 min was the most abundant forager followed by Megachile sp. with 4.08, 5.05 and 2.53 bees $/$ branch $/ 5 \mathrm{~min}$. The lepidopteran at $0.59,0.85,0.41$ insects/ branch $/ 5 \mathrm{~min}$ and dipteran $0.62,1.15,0.60$ insects/branch/5min were significantly lower than the Apis dorsata 2.8 and 1.78 bees/branch/5min during all three intervals. The interaction between the insect visitors and hours showed that in first and third interval have lower insect abundance when it is compared with than second interval throughout the period of observations.

\section{Documentation of pollinators on Phalsa}

Present findings of diversity of pollinators are in line with Gill (2001) who documented a total number of 21 insect species (Hymenoptera 10; Lepidoptera 7 and Diptera 4) from the flowers of Phalsa, among these Apis florea F. Apis mellifera L., Apis dorsata F. Megachile bicolour F. and Chalicodoma cephalotes smith were observed foraging on both nectar and pollen. 
Table.1 Documentation of various insect pollinators on Phalsa flowers 2015

\begin{tabular}{|c|c|c|c|}
\hline Common name & Scientific name & Family & Order \\
\hline Leaf cutter bees & $\begin{array}{l}\text { Megachile lanata } \\
\text { Coelioxys apicata } \\
\text { Megachile sp. }\end{array}$ & Megachilidae & \multirow{10}{*}{ Hymenoptera } \\
\hline $\begin{array}{l}\text { Yellow banded } \\
\text { wasp }\end{array}$ & Vespa orientalis & Vespidae & \\
\hline $\begin{array}{l}\text { Common paper } \\
\text { wasp }\end{array}$ & Polistes olivaceus & & \\
\hline Italian bee & Apis mellifera & \multirow[t]{5}{*}{ Apidae } & \\
\hline Giant bee & Apis dorsata & & \\
\hline Indian bee & Apis cerena indica & & \\
\hline Little bee & Apis florea & & \\
\hline Stingless bee & $\begin{array}{l}\text { Tetragonula } \\
\text { iridipennis }\end{array}$ & & \\
\hline $\begin{array}{l}\text { Sweat bees or } \\
\text { Halictid bees }\end{array}$ & Halictus spp. & Halictidae & \\
\hline Carpenter bees & $\begin{array}{l}\text { Xylocopafenestrate } \\
\text { Xylocopa } \\
\text { pubescence }\end{array}$ & Xylocopidae & \\
\hline \multirow[t]{2}{*}{ Flesh fly } & Sarcophaga spp. & sarcophagidae & \multirow{3}{*}{ Diptera } \\
\hline & Chrysomya spp. & Calliphoridae & \\
\hline Hover fly & $\begin{array}{l}\text { Eristalinus } \\
\text { tabanoides }\end{array}$ & Syrphidae & \\
\hline Pioneer white & Anaphaeis aurota & Pieridae & \multirow{3}{*}{ Lepidoptera } \\
\hline \multirow[t]{2}{*}{ African monarch } & $\begin{array}{l}\text { Danaus } \\
\text { chrysippus }\end{array}$ & Nymphalidae & \\
\hline & Amata passelis & Amatidae & \\
\hline
\end{tabular}


Table.2 Relative abundance of different insect pollinators on Phalsa during 2015

\begin{tabular}{|c|c|c|c|c|c|c|c|c|c|c|c|c|}
\hline \multirow{3}{*}{$\begin{array}{c}\text { Insect } \\
\text { Pollinators }\end{array}$} & \multicolumn{12}{|c|}{ Number of pollinators / Branch/5 minutes during different day hours } \\
\hline & \multicolumn{4}{|c|}{8 April to 17 April } & \multicolumn{4}{|c|}{19 April to 28 April } & \multicolumn{4}{|c|}{30 April to 09 May } \\
\hline & $\begin{array}{l}08.00- \\
10.00\end{array}$ & $\begin{array}{l}10.00- \\
12.00\end{array}$ & $\begin{array}{c}14.00- \\
16.00\end{array}$ & Mean & $\begin{array}{l}08.00- \\
10.00\end{array}$ & $\begin{array}{l}10.00- \\
12.00\end{array}$ & $\begin{array}{l}14.00- \\
16.00\end{array}$ & Mean & $\begin{array}{c}08.00- \\
10.00\end{array}$ & $\begin{array}{l}10.00- \\
12.00\end{array}$ & $\begin{array}{r}14.00- \\
16.00\end{array}$ & Mean \\
\hline A.dorsata & $\begin{array}{c}3.44 \\
(1.98)\end{array}$ & $\begin{array}{c}2.86 \\
(1.83)\end{array}$ & $\begin{array}{c}2.30 \\
(1.67)\end{array}$ & $\begin{array}{c}2.87 \\
(1.83)\end{array}$ & $\begin{array}{c}4.74 \\
(2.29)\end{array}$ & $\begin{array}{c}3.83 \\
(2.08)\end{array}$ & $\begin{array}{c}3.37 \\
(1.97)\end{array}$ & $\begin{array}{c}3.98 \\
(2.11)\end{array}$ & $\begin{array}{c}2.86 \\
(1.83)\end{array}$ & $\begin{array}{c}1.43 \\
(1.39)\end{array}$ & $\begin{array}{c}1.18 \\
(1.29)\end{array}$ & $\begin{array}{c}1.82 \\
(1.51)\end{array}$ \\
\hline A.mellifera & $\begin{array}{c}3.02 \\
(1.87)\end{array}$ & $\begin{array}{c}2.61 \\
(1.76)\end{array}$ & $\begin{array}{c}2.14 \\
(1.62)\end{array}$ & $\begin{array}{c}2.59 \\
(1.75)\end{array}$ & $\begin{array}{c}3.99 \\
(2.11)\end{array}$ & $\begin{array}{c}3.47 \\
(1.99)\end{array}$ & $\begin{array}{c}2.98 \\
(1.86)\end{array}$ & $\begin{array}{c}3.48 \\
(1.99)\end{array}$ & $\begin{array}{c}2.11 \\
(1.61)\end{array}$ & $\begin{array}{c}1.39 \\
(1.37)\end{array}$ & $\begin{array}{c}1.10 \\
(1.26)\end{array}$ & $\begin{array}{c}1.53 \\
(1.42)\end{array}$ \\
\hline Halictus sp & $\begin{array}{c}5.21 \\
(2.39)\end{array}$ & $\begin{array}{c}4.54 \\
(2.24)\end{array}$ & $\begin{array}{c}4.22 \\
(2.17)\end{array}$ & $\begin{array}{c}4.66 \\
(2.27)\end{array}$ & $\begin{array}{c}6.32 \\
(2.61)\end{array}$ & $\begin{array}{c}5.56 \\
(2.46)\end{array}$ & $\begin{array}{c}4.92 \\
(2.33)\end{array}$ & $\begin{array}{c}5.6 \\
(2.47)\end{array}$ & $\begin{array}{c}3.16 \\
(1.91)\end{array}$ & $\begin{array}{c}2.96 \\
(1.86)\end{array}$ & $\begin{array}{c}2.46 \\
(1.72)\end{array}$ & $\begin{array}{c}2.86 \\
(1.83)\end{array}$ \\
\hline $\begin{array}{c}\text { Polistes } \\
\text { olivaceus }\end{array}$ & $\begin{array}{c}2.84 \\
(1.82)\end{array}$ & $\begin{array}{c}2.41 \\
(1.70)\end{array}$ & $\begin{array}{c}2.35 \\
(1.68)\end{array}$ & $\begin{array}{c}2.53 \\
(1.74)\end{array}$ & $\begin{array}{c}3.53 \\
(2.00)\end{array}$ & $\begin{array}{c}3.18 \\
(1.91)\end{array}$ & $\begin{array}{c}2.78 \\
(1.81)\end{array}$ & $\begin{array}{c}3.16 \\
(1.91)\end{array}$ & $\begin{array}{c}1.95 \\
(1.56)\end{array}$ & $\begin{array}{c}1.81 \\
(1.51)\end{array}$ & $\begin{array}{c}1.51 \\
(1.41)\end{array}$ & $\begin{array}{c}1.76 \\
(1.50)\end{array}$ \\
\hline Megachile sp. & $\begin{array}{c}4.74 \\
(2.29)\end{array}$ & $\begin{array}{c}4.02 \\
(2.13)\end{array}$ & $\begin{array}{c}3.49 \\
(2.00)\end{array}$ & $\begin{array}{c}4.08 \\
(2.14)\end{array}$ & $\begin{array}{c}5.61 \\
(2.47)\end{array}$ & $\begin{array}{c}5.1 \\
(2.36)\end{array}$ & $\begin{array}{c}4.43 \\
(2.22)\end{array}$ & $\begin{array}{c}5.05 \\
(2.35)\end{array}$ & $\begin{array}{c}2.80 \\
(1.89)\end{array}$ & $\begin{array}{c}2.55 \\
(1.75)\end{array}$ & $\begin{array}{c}2.22 \\
(1.64)\end{array}$ & $\begin{array}{c}2.53 \\
(1.74)\end{array}$ \\
\hline Lepidoptera & $\begin{array}{c}0.62 \\
(1.06)\end{array}$ & $\begin{array}{c}0.64 \\
(1.07)\end{array}$ & $\begin{array}{c}0.50 \\
(1.00)\end{array}$ & $\begin{array}{c}0.59 \\
(1.04)\end{array}$ & $\begin{array}{c}1.00 \\
(1.22)\end{array}$ & $\begin{array}{c}0.87 \\
(1.17)\end{array}$ & $\begin{array}{c}0.67 \\
(1.08)\end{array}$ & $\begin{array}{c}0.85 \\
(1.16)\end{array}$ & $\begin{array}{c}0.64 \\
(1.06)\end{array}$ & $\begin{array}{c}0.35 \\
(0.92)\end{array}$ & $\begin{array}{c}0.23 \\
(0.85)\end{array}$ & $\begin{array}{c}0.41 \\
(0.95)\end{array}$ \\
\hline Diptera & $\begin{array}{c}0.64 \\
(1.07)\end{array}$ & $\begin{array}{c}0.56 \\
(1.03)\end{array}$ & $\begin{array}{c}0.67 \\
(1.03)\end{array}$ & $\begin{array}{c}0.62 \\
(1.04)\end{array}$ & $\begin{array}{c}1.20 \\
(1.30)\end{array}$ & $\begin{array}{c}1.23 \\
(1.31)\end{array}$ & $\begin{array}{c}1.01 \\
(1.23)\end{array}$ & $\begin{array}{c}1.15 \\
(1.28)\end{array}$ & $\begin{array}{c}0.69 \\
(1.09)\end{array}$ & $\begin{array}{c}0.64 \\
(1.07)\end{array}$ & $\begin{array}{c}0.47 \\
(0.98)\end{array}$ & $\begin{array}{c}0.6 \\
(1.05)\end{array}$ \\
\hline Mean & $\begin{array}{c}2.93 \\
(1.76)\end{array}$ & $\begin{array}{c}2.52 \\
(1.66)\end{array}$ & $\begin{array}{c}2.24 \\
(1.59)\end{array}$ & & $\begin{array}{c}3.77 \\
(1.98)\end{array}$ & $\begin{array}{c}3.32 \\
(1.87)\end{array}$ & $\begin{array}{c}2.88 \\
(1.76)\end{array}$ & & $\begin{array}{c}2.03 \\
(1.54)\end{array}$ & $\begin{array}{c}1.59 \\
(1.40)\end{array}$ & $\begin{array}{c}1.31 \\
(1.30)\end{array}$ & \\
\hline SEm \pm & & & & 0.054 & & & & 0.067 & & & & 0.049 \\
\hline CD at $5 \%$ & & & & 0.158 & & & & 0.195 & & & & 0.142 \\
\hline
\end{tabular}

Figures in the parenthesis are square root transformed values 


\section{Relative abundance of different insect pollinators}

The maximum activity of the insects can be seen morning and noon session this results coincides with work of Randhawa and Dass (1962) and Parmar (1976) who recorded maximum activity of floral visitors in Phalsa was during 8.00AM to 12.00 Noon. After that there are no studies on pollination activity in Phalsa. However, over the years there reliance of insect pollinators on Phalsa has remained unchanged strikingly.

Halictus sp. was found most abundant followed by Megachile sp. And Apis dorsata.The present study justifies the observations of Kumar (2010) who reported that Halictus sp. as most abundant visitor among three bee species. Similarly Trigona spp., Halictus sp. and lepidopterans were the most frequent visitors among the different insect pollinators on $M$. charantia flowers in Philippines as per Deyto and Cervancia (2009).

\section{References}

Deyto, R.C. and Cervancia, C.R. (2009). Floral biology and pollination of Ampalaya (Momordica charantia L.). Philipp. Agri. Scientist, 92(1): 8-18.

Gill, S. S., Kaushik, H. D. and Sharma S. K. (2001). Effect of modes of pollination on fruit set and insect pollinators of Phalsa (Grewia subinaequalis D. C.). Res. on Crops 2 (2): 193-196.

Gomez, K.A. and Gomez, A.A. (1984).
Statistical procedures, John Wiley and sons, Pp. 644-655.

Kumar, B.P. (2010). Studies on insect pollinators on Bitter gourd (Momordica charantia L.) M.Sc. Thesis, Haryana Agricultural University, Hisar, Haryana, India, $15 \mathrm{pp}$

Mishra, R.K., Patel, S.P., Srivastava, A., Vashistha, R.K., Singh, A. and Puskar, A.K. (2012) Ethnomedicinally important plants of Pachmarhi region, Madhya Pradesh, India. Nat. Sci J.10, 22-26.

Pallavi, K., Singh, R., Singh, S., Singh, K., Farswan, M. And Singh, V., (2011). Aphrodisiac agents from medicinal plants: a review. J. Chem. Pharm. Res. 3, 911-921.

Parmar, (1976). Pollination and fruit set in Phalsa (Grewia asiatica L.) Agri. Agro. Industries, J. 9 (6): 12-14.

Randhawa, G. S. and Dass, H. C. (1962). Studies on floral biology of Phalsa (Grewia astiatica L.) Indian J. Hort. 19(1): 10-24.

Sharma, K.V. and Sisodia, R. (2009). Evaluation of the free radical scavenging activity and radioprotective efficacy of Grewia asiatica fruit. J. Radiol. Prot. 29, 429443.

Ullah, W., Uddin, G. and Siddiqui, B.S. (2012). Ethnic uses, pharmacological and phytochemical profile of genus Grewia. J. Asian Nat. Prod. Res. 14, 186-195.

\section{How to cite this article:}

Avinash Udikeri and Umesh Chandra. 2019. Diversity and Abundance of Pollinators Fauna in Phalsa Grewia subinaequalis D.C. Int.J.Curr.Microbiol.App.Sci. 8(02): 2199-2204. doi: https://doi.org/10.20546/ijcmas.2019.802.254 